\title{
Physico-Chemical Characterization and Speciation of Sulphur of Nigerian Coal Samples
}

\author{
Folahan A. Adekola*, Alafara A. Baba, Sherifat Buhari \\ Department of Chemistry, University of Ilorin, Ilorin, Nigeria \\ Email: *faadekola@yahoo.fr, fadekola@unilorin.edu.ng
}

Received July 27, 2012; revised August 29, 2012; accepted September 10, 2012

\begin{abstract}
Studies of physico-chemical characterization, and chemical speciation of sulphur of seven Nigerian coal samples have been undertaken. The seven coal samples originated from South-east, North-central and North-east of Nigeria where there are proven economic deposits of this mineral. Moisture content, bulk density, percentage ash and loss of mass on ignition of all the coal samples were determined. The ultimate analysis of the raw coal, the corresponding coal ash as well as sulphur content of all samples were carried out with the aid of X-ray fluorescence technique (XRF). The major elements were $\mathrm{Fe}$, Ca and S while the minor metals were $\mathrm{K}, \mathrm{Sc}, \mathrm{Zn}, \mathrm{Ni}$, Ti and Zr. Other metals including $\mathrm{Ga}, \mathrm{Cu}, \mathrm{Mn}$, $\mathrm{Cr}$ and $\mathrm{V}$ were found in traces. The Nickel/Vanadium ratio which is a means of providing information on the source rock depositional environment ranged between 8.8 - 32.9. Three different source rock depositional environments were deduced for the coals from their nickel/vanadium ratios, while the calculated values of $\mathrm{V} /(\mathrm{V}+\mathrm{Ni})$ suggested that they were all formed under oxic condition. The three chemical species of sulphur, sulphate, pyritic and organic sulphur in the seven coal samples were determined using the ASTM method.
\end{abstract}

Keywords: Sulphur Speciation; Nigerian Coal; X-Ray Fluorescence Analysis; Heavy Metals

\section{Introduction}

Coal can be defined as a chemically and physically heterogeneous, "combustible", sedimentary rock consisting of both organic and inorganic materials. Organically, coal consists primarily of carbon, hydrogen, and oxygen, with lesser amounts of sulphur and nitrogen. Inorganically, coal consists of a diverse range of ash-forming compounds distributed throughout the coal [1].

Coal is classified into four general categories, or "ranks". They range from lignite through subbituminous and bituminous to anthracite, reflecting the progressive response of individual deposits of coal to increasing heat and pressure. The carbon content of coal supplies most of its heating value, but other factors also influence the amount of energy it contains per unit of weight [2].

The sulphur content of coal varies considerably with the nature and origin of the fossil deposits [3]. Sulphur in coal is present in both inorganic and organic forms. The inorganic sulphur in coal consists predominantly of sulphides (pyrite $\left(\mathrm{FeS}_{2}\right)$, sphalerite $(\mathrm{ZnS})$, galena $(\mathrm{PbS})$, arsenopyrite (FeAsS) and others) and sulphates (barite $\left(\mathrm{BaSO}_{4}\right)$, gypsum $\left(\mathrm{CaSO}_{4} \cdot 2 \mathrm{H}_{2} \mathrm{O}\right)$, anhydrite $\left(\mathrm{CaSO}_{4}\right)$, and a number of iron sulphates and others) [4]. Pyrite is generally the preponderant inorganic sulphur in coal.

\footnotetext{
"Corresponding author.
}

Particles of pyrite are randomly distributed as crystals throughout the coal but are not bound to it [5].

The organic sulphur in coal is covalently bound into its large complex structure and is difficult to remove physiccally or chemically, in contrast to pyritic or inorganic sulphur [6]. The organic sulphur in coal exists as both aliphatic and aromatic or heterocyclic forms, which can be classified into four groups [7]: aliphatic or aromatic thiols (mercaptans, thiophenols); aliphatic, aromatic, or mixed sulphides (thioethers); aliphatic, aromatic, or mixed disulphides (dithioethers) and heterocyclic compounds or the thiophene type (dibenzothiophenes).

The utilization of coals for both energy production and various coal conversion processes is limited by the presence of sulphur in the coal. The high sulphur dioxide emissions caused by the utilization of coals as a major fossil fuel leads to worldwide environmental problems [8]. When coal is burnt its sulphur content combines with oxygen to form sulphur dioxide $\left(\mathrm{SO}_{2}\right)$, which contributes to both pollution and acid rain [9]. Acid rain resulting from $\mathrm{SO}_{2}$ has a harmful effect on agriculture and destroys the ecological balance [10]. The presence of sulphur in coal also reduces the quality of metallurgical coal $[11,12]$. Therefore, it is necessary to remove the mineral matter and sulphur from coal prior to its utilization.

Nigeria has major coal resources that have not been 
well explored or exploited. The coal reserves in Nigeria are estimated to be in excess of 2.5 billion tonnes and they are mainly of sub-bituminous type. The government has prioritized the use of these resources in order to deal with the country's power supply problems [13].

Several studies have been carried out on the trace metal characterization of coals from various locations in Nigeria using mainly Atomic Absorption spectrometry (AAS). There has been important underestimation of the levels of metals due to incomplete wet digestion of the coal materials on one hand and as a result of limited capacity of this technique when compared to modern instrumental techniques such as XRF. Moreover, most of the works reported concerned the raw coal samples and with lack of information on the coals' ashes residues. This study has therefore been conceived with the view of carrying out comprehensive trace metal analysis of not only the coal materials but in addition, their corresponding ashes residues.

Furthermore, there is dearth of information on the chemical forms of sulphur in Nigerian coals which is a pre-condition for assessing its suitability for use in a coal-fired plant. The objectives of the present investigation were therefore to carry out physico-chemical characterization of some Nigerian coal samples, determine the various chemical forms of sulphur in these coals.

\section{Experimental Section}

\subsection{Sample Collection}

All coal samples used were obtained either from the Nigerian Coal Corporation, Enugu or the National Metallurgical Research Centre, Jos, Nigeria. The coal samples originated from the following seven coal mining fields in Nigeria:

Onyeama(OYM), Okpara (OKP), Okaba (OKB), Iva (IVA), Chikila (CKL), Lafia Obi (LFB) and Jankwa Shakodi (JKS).

\subsubsection{Sample Pre-Treatment}

The selected lumps of coal samples were air-dried and then pulverized with clean mortar and pestle and sieved into selected mesh powder. The powdered samples with particles diameter less than $50 \mathrm{~mm}$ were retained for all investigations.

\subsubsection{Physico-chemical characterization of Materials} The physic-chemical parameters analysed for in the coal samples were moisture content, bulk density, loss of mass on ignition, ash content, sulphur and metals.

Moisture content was determined by heating to a constant weight using a MINO/53/CLAD oven at a temperature of $105^{\circ} \mathrm{C}$ for three hours [14]; The bulk density of coal samples was determined following a simple displacement procedure based on the Archimede's principle [14]; The loss of mass on ignition and the ash content were determined by heating the sample to constant weight at $650^{\circ} \mathrm{C}$ for three hours in the carbolite ELF $11 / 148$ muffled furnace [14]. The elemental composition of the coal samples were carried out with the aid of Energy Dispersive-X-ray fluorescence spectrophotometer (EDXRF), Philip's model 12045 B4/3. The total sulphur in coal samples was determined with ED-XRF. While Sulphate-S and Pyritic-S in the coals were carried out using standard ASTM methods [15]. Organic sulphur was determined by difference.

\section{Results and Discussion}

Physico-chemical characteristics of seven different coal samples from Nigeria are summarized in Table 1.

Chikila coal has the highest moisture content with value of $7.1 \%$ while Jankwa Shankodi has the lowest moisture content of $1.3 \%$. Onyeama, Okpara and Iva coals have moisture contents of $2.6 \%, 3.1 \%$ and $4.1 \%$ respectively which are very close to the value of $3.5 \%$ earlier reported by Onwu [16] for Enugu coals.

\subsection{Total Elemental Analysis}

The results of elemental analysis of the coal obtained with the aid of ED-XRF are given in Table 2.

It is evident from the ED-XRF results that there is variation in abundance of various elements in all the coal samples investigated. In Onyeama coal, sulphur occurred

Table 1. Proximate analysis of Nigerian coal samples.

\begin{tabular}{ccccc}
\hline Samples & Moisture content (\%) & Bulk density $\left(\mathrm{g} / \mathrm{cm}^{3}\right)$ & Loss of mass on ignition (\%) & Ash content (\%) \\
\hline Onyeama & 2.6 & 0.71 & 83.7 & 16.3 \\
Okpara & 3.1 & 0.69 & 93.4 & 6.7 \\
Okaba & 4.3 & 0.73 & 91.0 & 9.4 \\
Iva & 4.1 & 0.69 & 93.4 & 6.7 \\
Chikila & 7.1 & 1.37 & 75.7 & 23.4 \\
Lafia obi & 1.5 & 1.29 & 87.4 & 12.9 \\
Jankwa shankodi & 1.3 & 1.20 & 79.9 & 20.1 \\
\hline
\end{tabular}


Table 2. Sulphur and metals analysis of some Nigerian coal samples.

\begin{tabular}{|c|c|c|c|c|c|c|c|}
\hline Element & Onyeama & Okpara & Okaba & Iva & Chikila & Lafia obi & Jankwa S. \\
\hline S (ppm) & $3015 \pm 249$ & $8614 \pm 1414$ & $7002 \pm 1204$ & $2996 \pm 255$ & $7811 \pm 398$ & $3503 \pm 281$ & $4511 \pm 286$ \\
\hline $\mathrm{K}(\mathrm{ppm})$ & $213 \pm 12.1$ & $667 \pm 73.4$ & $792 \pm 76$ & $106 \pm 12$ & $401 \pm 19$ & $185 \pm 16$ & $291 \pm 20$ \\
\hline $\mathrm{Ca}(\mathrm{ppm})$ & $533 \pm 41$ & $9751 \pm 100$ & $8201 \pm 101.8$ & $3852 \pm 10.2$ & $1.604 \pm 0.01$ & $355 \pm 41$ & $5966 \pm 121$ \\
\hline Sc(ppm) & $32.8 \pm 4.6$ & $1223 \pm 176$ & $1061 \pm 159$ & $168.9 \pm 19.1$ & $414 \pm 40.3$ & $64.2 \pm 11$ & $84 \pm 9$ \\
\hline $\mathrm{Ti}(\mathrm{ppm})$ & $784 \pm 17.1$ & $15,010 \pm 0.03$ & $13,000 \pm 0.02$ & $1559 \pm 26$ & $1342.1 \pm 34$ & $356.1 \pm 15$ & $691.7 \pm 21$ \\
\hline V(ppm) & $8.11 \pm 1.7$ & $137 \pm 7.81$ & $106.3 \pm 7$ & $15 \pm 3$ & $15.2 \pm 1$ & $9 \pm 3$ & $9.1 \pm 1$ \\
\hline Cr(ppm) & $11 \pm 1.4$ & $86 \pm 8.03$ & $50.6 \pm 6.1$ & $13.1 \pm 1.1$ & $21.1 \pm 4$ & $14.9 \pm 2$ & $13.01 \pm 3$ \\
\hline $\mathrm{Mn}(\mathrm{ppm})$ & $45.81 \pm 2.4$ & $130.2 \pm 8$ & $86 \pm 5.8$ & $155.8 \pm 5$ & $69 \pm 3$ & $62.3 \pm 2$ & $51.97 \pm 3$ \\
\hline $\mathrm{Fe}(\%)$ & $7.11 \pm 0.051$ & $5.02 \pm 0.051$ & $5.585 \pm 0.07$ & $7.771 \pm 0.04$ & $7.1 \pm 0.03$ & $9.07 \pm 0.04$ & $8.72 \pm 0.031$ \\
\hline $\mathrm{Ni}(\mathrm{ppm})$ & $87.1 \pm 10$ & $1450.8 \pm 69$ & $933.1 \pm 53.02$ & $149.2 \pm 14.1$ & $277 \pm 21$ & $296 \pm 21$ & $158 \pm 17$ \\
\hline $\mathrm{Cu}(\mathrm{ppm})$ & $63 \pm 5.2$ & $290.3 \pm 21$ & $279.7 \pm 18.4$ & $74.8 \pm 6.3$ & $88.1 \pm 5.9$ & $64.9 \pm 6.2$ & $81 \pm 9$ \\
\hline $\mathrm{Zn}(\mathrm{ppm})$ & $231 \pm 17.2$ & $861 \pm 55$ & $1081 \pm 57$ & $199 \pm 18$ & $529.93 \pm 29$ & $463 \pm 27$ & $465 \pm 27$ \\
\hline Ga(ppm) & $77 \pm 5.6$ & $345.3 \pm 25.2$ & $290.8 \pm 22$ & $84.01 \pm 8.8$ & $69.2 \pm 7$ & $69 \pm 6.4$ & $50.6 \pm 4.4$ \\
\hline $\mathrm{Zr}(\mathrm{ppm})$ & $178 \pm 8$ & $219 \pm 21$ & $144.6 \pm 17.8$ & $99.02 \pm 9$ & $42.01 \pm 5.1$ & $24.1 \pm 4$ & $33.1 \pm 5$ \\
\hline
\end{tabular}

as the major element, while $\mathrm{K}, \mathrm{Ca}, \mathrm{Ti}, \mathrm{Zn}$ and $\mathrm{Zr}$ occurred as minor elements and Sc, V, Cr, Mn, Fe, Ni, Cu and $\mathrm{Ga}$ occurred in trace elements. S, Ca, Sc and Ni are present as major elements while $\mathrm{K}, \mathrm{V}, \mathrm{Mn}, \mathrm{Cu}, \mathrm{Zn}, \mathrm{Ga}$, $\mathrm{Zr}$ occurred as minor elements and $\mathrm{Ti}, \mathrm{Ga}$ and $\mathrm{Fe}$ occurred as trace elements in Okpara coal. Okaba coal from Kogi state has S, Ca, Sc, and Zn as major elements while $\mathrm{K}, \mathrm{V}, \mathrm{Ni}, \mathrm{Cu}, \mathrm{Ga}$ and $\mathrm{Zr}$ occurred as minor elements and $\mathrm{Ti}, \mathrm{Cr}, \mathrm{Mn}$ and $\mathrm{Fe}$ are the trace elements present. In Iva coal, S, Ca, and Ti occurred as major elements while $\mathrm{K}$, $\mathrm{Sc}, \mathrm{Mn}, \mathrm{Ni}$ and $\mathrm{Zn}$ occurred as minor and V, Cr, Fe, Cu, Ga and Zr occurred as trace elements.

Chikila has $\mathrm{S}$ and $\mathrm{Ti}$ as major elements while K, Sc, Ni and $\mathrm{Zn}$ are the minor elements and $\mathrm{Ca}, \mathrm{V}, \mathrm{Cr}, \mathrm{Mn}, \mathrm{Fe}, \mathrm{Cu}$, $\mathrm{Ga}$ and $\mathrm{Z}$. $\mathrm{r}$ are the trace elements present.

Sulphur is the only major element while $\mathrm{K}, \mathrm{Ca}, \mathrm{Ti}, \mathrm{Ni}$ and $\mathrm{Zn}$ are present as minor element and Sc, V, Cr, Mn, $\mathrm{Fe}, \mathrm{Cu}$ and $\mathrm{Ga}$ are present as a trace element in the Lafia obi coal. In Jankwa shankodi S and Ca are major elements present while $\mathrm{K}, \mathrm{Ti}, \mathrm{Ni}$, and $\mathrm{Zn}$ are present as the minor elements and Sc, V, Cr, Mn, Fe, Cu, Ga and Zr are the trace element present. It is important to note that significantly higher values were measured for all metals when compared to some previous studies [17-19]. This could be adduced to the inefficiency of the digestion procedures adopted by these authors prior to AAS analysis. This was unlike the XRF technique used in this study which enabled a direct analysis of solid materials and thus, avoiding a preliminary acid digestion of coal samples. It is also worthy of note that some coal samples (Iva, Okpara, Chikila, Okaba and Onyeama) are very rich in titanium metal and this could be an indication of presence of titanium-rich minerals such as $\mathrm{TiO}_{2}$ and $\mathrm{FeTiO}_{3}$ $[19,20]$. Okaba and Okpara also exhibited high concen- tration of zinc and nickel. The high concentration of zinc could be an indication of the presence of sphalerite mineral in thess areas [21] In terms of the degree of the elemental analysis using, it is observed that Jankwa Shankodi has the highest total metal concentration (102600.0 ppm) while Onyeama has the least (12,382 ppm). In terms of degree of mineralization, the results show that the three coal samples (Chikila, Lafia obi and Jankwa shankodi) from the northern region of the country are highly mineralized based on their total metal content.

The presence of Vanadium in traces (9.0 - 106.3 ppm) for all the coal samples is an indication of low maturity and marine/terrestrial sourced coal [19].

The values of $\mathrm{Ni} / \mathrm{V}$ ratio are presented in Table 3 and they range between 8.8 - 32.9. $\mathrm{Ni} / \mathrm{V}$ ratio has been used by several authors as a means of providing information on the source rock depositional environment $[18,19]$.

The seven coal types investigated in this work appear to fall into three distinct groups based on $\mathrm{Ni} / \mathrm{V}$ ratio. Onyeama, Okpara, Okaba and Iva coals with lowest and practically the same $\mathrm{Ni} / \mathrm{V}$ ratio can be put in the same group. These coal samples can therefore be considered to

Table 3. The ratios of $\mathrm{Ni} / \mathrm{V}$ and $\mathrm{V} /(\mathrm{V}+\mathrm{Ni})$.

\begin{tabular}{lcc}
\hline Samples & $\mathrm{Ni} / \mathrm{V}$ & $\mathrm{V} / \mathrm{V}+\mathrm{Ni}$ \\
\hline Onyeama & 10.7 & 0.09 \\
Okpara & 10.6 & 0.09 \\
Okaba & 8.8 & 0.1 \\
Iva & 9.9 & 0.1 \\
Chikila & 18.2 & 0.05 \\
Lafia obi & 32.9 & 0.04 \\
Jankwa shankodi & 17.4 & 0.05 \\
\hline
\end{tabular}


have the same depositional environment.

The second group consists of Chikila and Jankwa shankodi with $\mathrm{Ni} / \mathrm{V}$ ratio of almost twice the $\mathrm{Ni} / \mathrm{V}$ ratio of the first group would also be considered to the same depositional environment. And lastly, Lafia obi coal with $\mathrm{Ni} / \mathrm{V}$ ratio of 32.9 which is thrice the value of the first group can be said to have a distinct depositional environment.

It is important to mention that the $\mathrm{Ni} / \mathrm{V}$ ratio calculated for Onyeama, Okpara and Okaba were much greater than the value earlier reported [19].

Futhermore V/V + Ni ratios are generally low for all the coal samples and this suggest that they were all formed under toxic conditions [19].

\subsection{Sulphur and Metal Analysis of Ashes from Coal Samples}

The results of elemental analysis of the ashes of the coal samples are presented in Table 4.

The coal ash elemental analysis gives the following concentrations.

Vanadium concentration ranges from 8 to $137 \mathrm{ppm}$ with an average of $42.71 \mathrm{ppm}$. Chromium concentration ranges from 12 to $86 \mathrm{ppm}$ with an average value of 29 ppm. The concentration of manganese ranges between 16 and $154 \mathrm{ppm}$ with an average value of $78.14 \mathrm{ppm}$ and the highest concentration was found in Iva coal while the lowest concentration was recorded in Lafia obi coal. Concentration of Nickel ranges from 86 to $1451 \mathrm{ppm}$ with the average value of $475.57 \mathrm{ppm}$; highest concentration of Nickel was recorded in Okpara coal and the least in Oyeama coal. The concentration of Zinc ranges between 197 to $1078 \mathrm{ppm}$ with the average of $541 \mathrm{ppm}$. Iron concentration ranges from $4.92 \%$ to $8.26 \%$ with an average value of $6.93 \%$. It was revealed from this work that coal beds are very rich source of some metals such as $\mathrm{Ni}, \mathrm{Ti}, \mathrm{Cu}, \mathrm{Fe}$ and $\mathrm{Cu}$. This indicates that the ash residue after burning would be a very good source of these metals and they can also be used to manufacture some other chemicals [19].

The sulphur content of the ashes is generally lower than values measured in the raw coal samples. The values in the ashes range from $2441-8247 \mathrm{ppm}$. The variation follows same trend as observed for the raw coal samples. The highest value was recorded for Okpara coal while the lowest was recorded for Lafia obi coal. The high level of Sulphur in the ash is an indication of the predominance of inorganic Sulphur (Sulphate and Pyritic Sulphur) in all the coal samples.

The analytical results obtained for the three chemical forms of sulphur in the coal samples are summarized in Table 5.

Table 4. Total metal analysis of coal ash.

\begin{tabular}{|c|c|c|c|c|c|c|c|}
\hline Elements & Onyeama & Okpara & Okaba & Iva & Chikila & Lafia obi & Jankwa shankodi \\
\hline $\mathrm{S}(\mathrm{ppm})$ & $2577 \pm 222$ & $8247 \pm 1372$ & $6476 \pm 1157$ & $2841 \pm 236$ & $6219 \pm 387$ & $2441 \pm 256$ & $3325 \pm 255$ \\
\hline $\mathrm{K}(\mathrm{ppm})$ & $200 \pm 11$ & $660 \pm 73$ & $791 \pm 76$ & $102 \pm 8$ & $329 \pm 19$ & $178 \pm 13$ & $285 \pm 14$ \\
\hline $\mathrm{Sc}(\mathrm{ppm})$ & $33 \pm 5$ & $1221 \pm 175$ & $1059 \pm 158$ & $168 \pm 19$ & $413 \pm 40$ & $63 \pm 11$ & $83 \pm 10$ \\
\hline $\mathrm{Ti}(\mathrm{ppm})$ & $784 \pm 17$ & $14,200 \pm 0.03$ & $12,400 \pm 0.02$ & $1557 \pm 26$ & $1341 \pm 32$ & $356 \pm 13$ & $691 \pm 18$ \\
\hline V (ppm) & $8 \pm 1$ & $137 \pm 8$ & $106 \pm 7$ & $15 \pm 1$ & $15 \pm 1$ & $9 \pm 1$ & $9 \pm 1$ \\
\hline Cr (ppm) & $10 \pm 1$ & $86 \pm 8$ & $50 \pm 6$ & $13 \pm 1$ & $18 \pm 2$ & $14 \pm 1$ & $12 \pm 1$ \\
\hline Mn (ppm) & $45 \pm 2$ & $128 \pm 8$ & $85 \pm 6$ & $154 \pm 3$ & $67 \pm 3$ & $16 \pm 2$ & $52 \pm 2$ \\
\hline $\mathrm{Fe}(\%)$ & $8.21 \pm 0.03$ & $4.92 \pm 0.05$ & $5.50 \pm 0.05$ & $7.76 \pm 0.03$ & $6.22 \pm 0.03$ & $8.26 \pm 0.04$ & $7.61 \pm 0.03$ \\
\hline $\mathrm{Ni}(\mathrm{ppm})$ & $86 \pm 8$ & $1451 \pm 69$ & $932 \pm 53$ & $150 \pm 14$ & $275 \pm 18$ & $294 \pm 18$ & $141 \pm 11$ \\
\hline $\mathrm{Cu}(\mathrm{ppm})$ & $51 \pm 5$ & $289 \pm 19$ & $278 \pm 18$ & $74 \pm 6$ & $85 \pm 6$ & $65 \pm 6$ & $72 \pm 6$ \\
\hline $\mathrm{Zn}(\mathrm{ppm})$ & $206 \pm 16$ & $854 \pm 53$ & $1078 \pm 57$ & $197 \pm 16$ & $528 \pm 26$ & $461 \pm 25$ & $463 \pm 25$ \\
\hline $\mathrm{Zr}(\mathrm{ppm})$ & $177 \pm 8$ & $219 \pm 21$ & $144 \pm 17$ & $99 \pm 9$ & $42 \pm 5$ & $24 \pm 4$ & $33 \pm 4$ \\
\hline
\end{tabular}

Table 5. Concentration (\%) of various chemical forms of sulphur in Nigerian coal samples.

\begin{tabular}{lccc}
\hline Samples & Total sulphur & Sulphate-S & Pyritic-S \\
\hline Onyeama & 0.302 & 0.082 & 0.176 \\
Okpara & 0.861 & 0.469 & 0.356 \\
Okaba & 0.700 & 0.337 & 0.054 \\
Iva & 0.300 & 0.008 & 0.311 \\
Chikila & 0.781 & 0.012 & 0.276 \\
Lafia obi & 0.350 & 0.002 & 0.610 \\
Jankwa S. & 0.451 & 0.047 & 0.242 \\
\hline
\end{tabular}


The results of suphur speciation revealed that pyriticsulphur is by far the most important form in Onyeama (58.2\%), Iva (92\%), Chikila (78.1\%), Lafia obi (69.1\%) and Jankwa shankodi (63.4\%) coals. Sulphate-sulphur constitutes $54.5 \%$ and $48.1 \%$ of total sulphur in Okpara and Okaba coals respectively. Organic-sulphur is generally very low in the coal samples except in Chikila, Lafia Obi and Jankwa Shankodi where it constitutes 20.4\%, $30.3 \%$ and $26.2 \%$ of the total suphur respectively.

\section{REFERENCES}

[1] B. G. Miller, “Coal Energy Systems,” Elsevier Academic Press, Burlington, 2005, p. 1.

[2] http://www.ket.org/Trips/Coal/AGSMM/agsmmtypes.htm 1

[3] K. S. Ryoo, J. Choi and Y. P. Hong, “Analysis of Sulfur in Coal and Coal Desulfurization by Counterflow Oxidative Treatment," Bulletin of the Korean Chemical Society, Vol. 21, No. 8, 2000, pp. 828-830.

[4] W. H. Calkins, "The Chemical Forms of Sulfur in Coal: A Review,” Fuel, Vol. 73, No. 4, 1994, pp. 475-484. doi:10.1016/0016-2361(94)90028-0

[5] W. Wise, “Coal, Water, Fuel Technology,” Workshop US Departmnet of Energy, Pittsburgh, ETCtr-Report-NO. BNL 51427. Pittsburgh, 1981.

[6] M. Constanti, J. Giralt and A. Bordons, "Desulphurization of Dibenzothiophene by Bacteria,” World Journal of Microbiology \& Biotechnology, Vol. 10, No. 5, 1994, pp. 510-516. doi:10.1007/BF00367655

[7] J. Klein, M. Van Afferden, F. Pfeifer and S. Schacht, "Microbial Desulfurization of Coal and Oil," Fuel Processing Technology, Vol. 40, No. 2-3, 1994, pp. 297-310. doi:10.1016/0378-3820(94)90152-X

[8] Y. Kadioglu, S. Bayrukceken and M. Gulaboglu, "The Removal of Organic Sulfur from Two Turkish Lignites by Chlorinolysis,” Turkish Journal of Chemistry, Vol. 22, No. 2, 1998, pp. 129-136.

[9] P. Prayuenyong, "Coal Biodesulfurization Processes," Songklanakarin Journal of Science and Technology, Vol. 24, No. 3, 2002, pp. 493-507.

[10] S. Ratanakandilok, S. Ngamprasertsith and P. Prasas- sarakich, "Coal Desulfurization with Methanol/Water and Methanol/KOH,” Fuel, Vol. 80, No. 13, 2001, pp. 19371942. doi:10.1016/S0016-2361(01)00047-3

[11] A. T. M. Mehliss, "Sulphur in South African Coal," Department of Mineral and Energy Affairs Report, The Bureau, Johannesburg, 1987.

[12] G. F. Morrison, “Chemical Desulfurization of Coal,” IEA Coal Research, London, 1981, pp. 43-45.

[13] http://www.tradeinvestnigeria.com/investment_opportunit ies/724113.html

[14] G. R. Blake and K. H. Hartage, "Bulk Density,” In A. Klute, Ed., Methods of Soil Analysis, part I, physical and mineralogical methods. Agronomy monograph, 2nd Edition, 1986, pp. 363-375.

[15] American Society for Testing and Materials (ASTM), “Annual Book of Standards, D2492-02," Standard Test Methods for Forms of Sulphur in Coal, American Society for Testing and Materials, Pennsylvania, 2007.

[16] D. O. Onwu, "Coal Fundamental and Conversion Technology,” Immaculate Publication, Enugu, 1999, p. 360.

[17] A. Jauro, A. Chigozie and M. B. Nasirudeen, "Determination of Selected Metals in Coal Samples from Lafia-Obi and Chikila," Science World Journal, Vol. 3, No. 2, 2008, pp. 79-81.

[18] A. A. Olajire, A. B. Ameen, M. Abdul-Hameed and F. A. Adekola, "Occurrence and Distribution of Metals and Porphyrins in Nigerian coal Minerals,” Journal of Fuel Chemistry and Technology, Vol. 35, No. 6, 2007, pp. 641-647. doi:10.1016/S1872-5813(08)60001-8

[19] T. A. Adedosu, H. O. Adedosu and F. M. Adebiyi, "Geochemical and Mineralogical Significance of Trace Metals in Benue through Coal, Nigeria," Journal of Applied Sciences, Vol. 7, No. 20, 2007, pp. 3101-3105. doi:10.3923/jas.2007.3101.3105

[20] K. O. Ipinmoroti and A. F. Aiyesanmi, "Trace Metals in the Bituminous Sands of Ondo State Nigeria,” Nigerian Journal of Science, Vol. 35, No. 1, 2001, pp. 63-68.

[21] O. A. Ehinola and A. F. Abimbola, "Prelimi Nary Assessement of Major and Trace Elements Content in the Middle Cretaceous Black Shales of the Abakaliki Fold Belt, Southeastern Nigeria,” Nafta, Vol. 53, No. 9, 2002, pp. 323-326. 